Friele, R.D., Kruikemeier, S., Rademakers, J.J.D.J.M., Coppen, R. Comparing the outcome of tyro different procedures to handle complaints from a patient's perspective. Journal of Forensic and

\begin{tabular}{|l|l|}
\hline $\begin{array}{l}\text { Postprint } \\
\text { Version }\end{array}$ & 1.0 \\
\hline Journal website & http://www.sciencedirect.com/science/article/pii/S1752928X12002429 \\
\hline Pubmed link & http://www.ncbi.nlm.nih.gov/pubmed/23622476 \\
\hline DOI & $10.1016 /$ j.jlm.2012.11.001
\end{tabular}

This is a NIVEL certified Post Print, more info at http://www.nivel.eu

\title{
Comparing the outcome of two different procedures to handle complaints from a patient's perspective
}

\author{
Roland D. Friele ${ }^{\mathrm{A}}$, ${ }^{\text {, }}$ (Prof., Dr., Health Services Researcher), SANNe \\ KRUIKEMEIER, MA ${ }^{\mathrm{C}}$ (SOCIOLOGIST), JANY J.D.J.M. RADEMAKERS ${ }^{\mathrm{A}}$ (DR., PSYCHOLOGIST), \\ REMCO COPPEN ${ }^{A}$ (DR., LAWYER) \\ ${ }^{a}$ NIVEL, Netherlands Institute for Health Services Research, Utrecht, The Netherlands \\ ${ }^{\mathrm{b}}$ Tranzo, Tilburg University, Tilburg, The Netherlands \\ ${ }^{c}$ Amsterdam School of Communication Research/ASCoR, University of Amsterdam, \\ Amsterdam, The Netherlands
}

\begin{abstract}
Aim of the study: To assess differences in patient satisfaction between a complaints procedure designed towards the needs of complainants (referred to here as the 'Committee') and a procedure that primarily aims at improving the professional quality of health care (referred to here as the 'Board').

Method: Patients' experiences and satisfaction were assessed through a questionnaire completed by 80 patients complaining to a Board and 335 to a complaints Committee. Only complainants with a complaint that was judged to be founded or partially founded were included.

Results: Only half of the complainants reported being satisfied with the procedure they underwent. After controlling for differences in respondent characteristics, satisfaction with the Board was higher than with the Committee. The level of variance explained, however, was low (3\%). The majority of respondents reported favourably on procedural aspects, for example, the impartiality of the procedure, and empathy demonstrated for their situation. Only a minority of complainants in both procedures believed that changes would be made as a result of their complaint.

Discussion: The absence, in the eyes of most complainants, of tangible results of filing a complaint in both rather formal procedures may serve as an explanation for both the low level of overall satisfaction and the fact that the procedure which was developed specifically for patients did not perform better. To resolve the problem of low satisfaction with complaints handling, procedures should be
\end{abstract}


Friele, R.D., Kruikemeier, S., Rademakers, J.J.D.J.M., Coppen, R. Comparing the outcome of tyro different procedures to handle complaints from a patient's perspective. Journal of Forensic and ) Legal Medicine: 2013, 20(4), 290-295

developed that offer a basic degree of procedural safety. But this procedural safety should not stand in the way of what complainants really want: changes for the better.

\section{INTRODUCTION}

Over the last decades, many countries have established procedures for complaint handling to resolve disputes between patients and healthcare providers. ${ }^{1,2}$ and 3 This development can be seen in the light of the growing interest in strengthening the patient's position in health care. ${ }^{4,5}$ and 6 Complaint handling may also serve as an instrument to develop or sharpen regulations and professional codes. ${ }^{7}$ It can offer health professionals and organisations an opportunity to improve the quality of healthcare provision based upon the feedback they receive from a patient filing a complaint. 8 , 9 and 10

Despite the effort different countries have made to install patient oriented complaint procedures, many patients who lodge a complaint are dissatisfied with the way their complaints are dealt with. ${ }^{1,11,12 \text { and } 13}$ An explanation for this has been sought in the discrepancy between what complainants expect or hope to get and what they actually get out of a complaints procedure. ${ }^{14,15}$ and 16 There are four motives which may lead to a complaint being filed: correction, communication, restoration and accountability. ${ }^{17 \text { and }}{ }^{18}$ Correction is one of the most frequently mentioned motives for lodging a complaint. Correction includes the assurance that lessons are learned from complainants' experiences. ${ }^{16}$ Complainants want to prevent a similar incident from happening in the future and they wish that others will not have to go through the same experience. They also want evidence that preventive or curative actions have been taken. ${ }^{11,14}$ and 17 The second most common motive is communication. Complainants want to know why and how the event arose, and they want an explanation or apology. ${ }^{11,14,16 \text { and } 17}$ As far as the third motive, restoration, is concerned, only a minority of the complainants want (financial) compensation, usually for (economic) losses caused by the incident that led to their complaint. ${ }^{11,14}$ and ${ }^{17}$ Restoration also includes the restoration of damage that has been done. The fourth motive is accountability: an individual or organisation should be held responsible for the complaint and punished. Previous research shows that a minority of the patients want the staff or professional to be disciplined. ${ }^{14 \text { and } 16}$ The failure to address these four motives, and especially the two most common cited ones correction and communication - may serve as an explanation for the dissatisfaction among patients with complaints procedures. ${ }^{1,17 \text { and } 19}$ Can the failure to meet patient's expectations for complaints handling be mended?

\subsection{Comparing two different complaint procedures}

\subsection{Comparing two different complaint procedures}

To answer this question we compared two different complaints procedures (Box 1). One was a complaints procedure at a Disciplinary Board; the other a Complaints Committee within hospitals that had been specifically set up for the benefit of patients. In many countries some form of Disciplinary Board for care providers exists. Among other functions, these Boards handle complaints about care providers in the interest of protecting society and to assure high professional practice standards. 
Friele, R.D., Kruikemeier, S., Rademakers, J.J.D.J.M., Coppen, R. Comparing the outcome of tyyo different procedures to handle complaints from a patient's perspective. Journal of Forensic and ) Legal Medicine: 2013, 20(4), 290-295

In the Netherlands, most complaints have been handled by such a Board for almost 90 years. They are part of the Dutch disciplinary system for health care professionals. The objective of the disciplinary system is to foster and monitor the quality of professional practice, to contribute to this quality and to protect the general public. ${ }^{2}$ and 20 The members of these Boards are legal experts and health professionals from the same profession as the accused. ${ }^{21}$ Patients may present their complaints to the Board directly without the need to first present the complaint somewhere else and without paying an entrance fee. The Board examines these complaints to judge whether the health care professional in question acted according to professional standards. If the accused is declared guilty of not conducting himself/herself accordingly, a variety of sanctions can be implemented (e.g., a warning, a reprimand, a suspension, a temporary work ban and revoking of licenses). ${ }^{2}{ }^{20}$ Verdicts may also be submitted for publication in professional journals.

\section{[BOX 1]}

Over the course of the years, disadvantages have emerged with this type of procedure. The number of justified cases within this procedure was found to be low (19\%) leading to the conclusion that the patient's position in this procedure was weak. ${ }^{21}$ It was considered that the existing complaints procedure was not organised to best suit the needs of the complainant. Therefore, in 1995, a new act was passed: The Clients Right of Complaint Act. ${ }^{22}$ This act made it compulsory for all health care professionals and institutions to appoint easily accessible Complaints Committees with independent chairs. ${ }^{17}$ Health care institutions mainly organised their own committee in house, whereas the professional organisations of individual practitioners, like general practitioners, set up committees on a regional or national level. Individual practitioners could participate in these committees. ${ }^{22}$ The aim of such a Committee is to focus explicitly on the legitimacy of the patient's complaint. Both the accused and the complainant have the opportunity to present their own views as well as to react to the other party's view. The procedure is rather formal in most cases, and is primarily based on the exchange of written statements by all the parties concerned. In its final verdict the Committee gives advice or recommends a solution to the health care provider or professional. The health care institution is then legally obliged to inform the patient whether or not (corrective) measures will be taken as a result of the complaint, as well as which measures will be taken. ${ }^{17}$ The Committee does not hold any formal power other than this. This complaints procedure was primarily established to provide patients with a legal right to a 'listening ear'.

Since two different systems exist to deal with complaints - both of which are directly accessible to patients and comprise no financial barriers - this affords a unique opportunity to assess the differences in patient's experiences with these different procedures. The aim of this paper is therefore to investigate whether a complaints procedure that was designed to focus on the needs of complainants results in more patients being satisfied with the way their complaints are dealt with than a procedure that primarily aims at improving the professional quality of health care. Based on the knowledge that the most prominent motives for complainants are communication and correction (in contrast to punishment), it would be expected that the complaints 
Friele, R.D., Kruikemeier, S., Rademakers, J.J.D.J.M., Coppen, R. Comparing the outcome of tyro different procedures to handle complaints from a patient's perspective. Journal of Forensic and ) Legal Medicine: 2013, 20(4), 290-295

procedure of the Committee will be more satisfying for complainants than the procedure of the Boards. The research questions for this study were:

1. Are patients that file a complaint to a Committee with a procedure that was developed with their needs in mind, more satisfied with the procedure than patients that file a complaint to a Disciplinary Board?

2. Can we explain any differences found (or not found) based on population characteristics, expectations or differences in the way complaints are treated?

\section{METHODS}

\subsection{Questionnaire}

A questionnaire was developed for patients who lodged a complaint to a Complaint Committee of the hospital or to a Disciplinary Board. This questionnaire was based on a questionnaire used in previous research. ${ }^{23}$ We checked the relevance of the questionnaire in five open interviews and two focus group discussions with in total 17 participants all of whom had filed a complaint against a care provider. The questionnaire contained five domains: (1) characteristics of the patients; (2) patients' motives to lodge a complaint; (3) patient's reports on the process of complaints handling and (4) the changes expected as a result of the complaint. This latter domain was included since earlier research had shown there was a difference between the appraisal by patients of the performance of the Committee on the one hand and the expectation that changes would be made by the care provider concerned on the other hand. ${ }^{17}$ These variables serve as independent variables. Overall patient's satisfaction

(5) is used as the dependent variable. Patient's motives (from 'not important' to 'most important'), reports on the procedure (from 'no' to 'yes') and satisfaction (from dissatisfied to satisfied) were all measured on a 4 point scale.

\subsection{Distribution and privacy}

The questionnaire was circulated to complainants from both the Disciplinary Boards and the Complaints Committees. Since only the Boards or the Committees had the names and addresses from complainants at their disposal, we asked them to distribute the questionnaires. All the Boards (5) and 61 (out of 95) Committees cooperated in the study. Reasons for not cooperating differed; for example, Committees 'did not want to bother the patients who lodge a complaint', 'received too few complaints per year' or 'there were objections from the hospital board'. The Boards and Committees distributed the questionnaires to the individual complainants. The complainants could send their completed questionnaires directly and anonymously to our research institute. Neither Boards nor Committees were involved in this part of the research. In other words, the distribution of the questionnaires was strictly separated from receiving and processing the completed questionnaires. This approach meant that it was not possible to send out reminders, hence a non-response analysis could not be carried out because questionnaires were returned anonymously, and therefore nonresponse could not be traced.

To guarantee the privacy of the respondents a privacy protocol was set up. Firstly, patient's responses were treated confidentially. Secondly, the patient's responses to the questionnaire would and could have no bearing on the conduct or outcome of the 
Friele, R.D., Kruikemeier, S., Rademakers, J.J.D.J.M., Coppen, R. Comparing the outcome of tyro different procedures to handle complaints from a patient's perspective. Journal of Forensic and ) Legal Medicine: 2013, 20(4), 290-295

complaints procedures. Thirdly, neither Committees, nor Boards, nor the accused saw the completed questionnaires and none of the parties knew which patients had participated in the study. Lastly, patients were entirely free to decide whether or not to complete the questionnaire. The protocol for this study was submitted to an external Medical Research Ethics Committee for formal ethical approval. This Committee concluded that formal ethical approval for this study was not required, since the study does not involve a medical intervention. Also the impact of the questionnaires on daily life was considered minor and thus the welfare and rights of the human participants were protected and they would not be harmed as a result of the study.

\subsection{Respondents}

Only patients were included whose complaints had been deemed founded or partially founded. Both samples were similar in this respect. Committees and Boards were asked to send the questionnaires to all their complainants (up to a maximum of 50 patients per Board/Committee) whose complaint had been deemed founded in a period of two years. This resulted in a postal questionnaire being sent to 206 patients who lodged a complaint to a Board, and to 750 patients who lodged a complaint to a Complaints Committee in a hospital. The questionnaire was returned to our institute by 80 patients who had lodged a complaint to a Board (response rate 39\%) and 335 patients who had lodged a complaint to a Committee (response rate $45 \%$ ).

\subsection{Analysis}

Differences between the scores for the Committee and the Board were tested using a

$T$-test for continuous variables, the Mann-Whitney rank-sum test for 4 point scales and for dichotomous variables the $\mathrm{chi}^{2}$-test. Differences in overall satisfaction with both procedures were tested using regression analysis, while controlling for relevant differences in patient characteristics and motives.

\section{RESULTS}

\subsection{Patient characteristics}

Overall, patients were highly educated, especially those complaining to the Disciplinary Board (Table 1). The majority of the patients considered the incident that caused their complaint to be very serious. Many reported physical, mental and financial consequences due to the incident. Patients complaining to the Boards reported financial consequences more frequently $(p=0.002)$ than those complaining to Committees (38\% versus 20\%). Also, complainants to the Boards more often made a claim for financial compensation.

\section{[TABLE 1]}

The majority of complaints concerned the medical treatment and/or the interpersonal conduct. In one third of the cases the complaint was reported to be related to a lack of information. Significantly more patients who lodged a complaint to a Committee complained about the organisation of care and nursing care. 
Friele, R.D., Kruikemeier, S., Rademakers, J.J.D.J.M., Coppen, R. Comparing the outcome of tyro different procedures to handle complaints from a patient's perspective. Journal of Forensic and ) Legal Medicine: 2013, 20(4), 290-295

\subsection{Patient's motives for lodging a complaint}

Motives for lodging a complaint to a Board or Committee were rather similar (Table 2). Nearly all patients wanted correction: e.g. to prevent the incident from happening again. Restoration of feelings of justice was also important to the majority of complainants. Being able to tell what happened was a motive for approximately half of both populations. For complainants to a Committee, significantly more wanted correction. Significantly more complainants to a Board wanted their feelings of justice to be restored and the accused to be punished.

\section{[TABLE 2]}

\subsection{Patient's experiences with the procedures}

About three quarters of respondents questioned reported that the Committee or the Board had remained impartial, that they had provided clear information on the procedure, they had explained the verdict, they were treated with respect, given room to tell what had happened, and had felt empathy demonstrated for their situation (Table 3). The differences between the two procedures became most evident in the reporting on results and impact of the compliant. Complainants to Boards reported less often that suggestions were made for change or that a new perspective to solving the problem had emerged. A quarter of the patients who lodged a complaint to a Committee thought that the hospital would make changes, whereas only one in ten of the patients who complained to a Board thought so. One in five of both the complainants to Boards and Committees thought that the individual health care professional would make changes.

\section{[TABLE 3]}

\subsection{Outcome: overall satisfaction}

$61 \%$ of the complainants to a Board expressed satisfaction with the complaints handling procedure compared with $47 \%$ of those filing complaints to a Committee. This difference was not statistically significant. One patient characteristic or motive and in which patients of either procedure significantly differed from each other was found to be significantly related to overall satisfaction. This was the motive to punish the accused; the less punishment desired, the more satisfied the complainant. When this variable was controlled for, the difference in overall satisfaction between both procedures became significant $(p=0.011)$. The percentage of variance in overall satisfaction explained by these variables was low: $3 \%$. All of the variables in Table 3 are individually related to overall satisfaction.

\section{DISCUSSION}

This study assessed whether a complaints procedure which was specifically designed for the benefits of patients would lead to more satisfaction among complainants than a procedure that was primarily designed to monitor and foster the quality of professional practice. Contrary to our expectations, the procedure that was designed for the benefit of patients did not lead to more patient satisfaction than the procedure that was designed to monitor and foster the quality of professional practice. 
Friele, R.D., Kruikemeier, S., Rademakers, J.J.D.J.M., Coppen, R. Comparing the outcome of tyye different procedures to handle complaints from a patient's perspective. Journal of Forensic and ) Legal Medicine: 2013, 20(4), 290-295

\subsection{Differences in populations}

Differences in demographic characteristics and motives were found, in addition to similarities. Apart from the fact that complainants to a Board more often reported financial consequences and said they would make a claim for financial compensation, no differences were found regarding either the degree to which the complaints gave rise to physical discomfort, pain, handicap or mental suffering, or in the nature of the complaints. In both procedures the motive of the majority of complainants was that of correction, in order to prevent the incident from happening again. This was especially evident amongst patients who filed a complaint to a Committee. The motive of communication was mentioned by about half of the complainants in both types of procedures. The motive of restoration, especially the restoration of the feeling of justice, was mentioned by more than half of the complainants, especially among complainants to a Board. Finally, the motive of accountability, to punish the accused, was mentioned more often by complainants to a Board. We conclude that both procedures attract populations that, among many similarities, demonstrate difference regarding their motives to lodge complaints. Complainants at the Committee seem to be more keen on correction, whereas complainants at the Board seem to be more keen on restoring their feelings of justice and on punishing the accused.

\subsection{Differences in complaint handling experiences}

Complainants reported equally positive experiences with the procedural conduct per se and with the empathy shown to them from the Board and the Committee.

However, the Committee does better on correction, as more complainants report that suggestions were made to the care provider for change. Also more complainants at the Committee believe that the hospital will implement changes.

\subsection{Strengths and limitations}

A strength of this study is the use of data from patients who lodged their complaint to different complaint procedures within one country. Data from patients who lodge their complaint to a Complaint Committee were compared to the patients who lodged their complaint to a Disciplinary Board. Both procedures are directly accessible for all patients in The Netherlands. This made it possible to compare the experiences of two complainants groups. A limitation of the study is that we ascertained patient's motives to lodge complaints through standardised (closed) questions. Some of the patients may not have been clear in their own mind as to what they were hoping to achieve. ${ }^{15}$ By giving standardised questions, direction was given to these motives. Nevertheless, the items in the questionnaire were based on earlier research and open interviews with patients who filed a complaint. A weakness of the study lies in the response-rates of $39 \%$ and $45 \%$. These rates are partially the result of our privacy policy, which did not allow us to send reminders. Response bias may have occurred. We do not think this to be a dominant effect. First our results are in line with earlier research. Second, this study focuses on the comparison of two populations. In both population non-response is rather similar, suggesting similar degrees of potential response bias. However, the possibility of response bias should be considered when interpreting these results. This study does not provide insight into the question of whether or not complaints lead to changes in health care. It only provides insight into whether or not complainants believe that changes will be made. 
Friele, R.D., Kruikemeier, S., Rademakers, J.J.D.J.M., Coppen, R. Comparing the outcome of tyye different procedures to handle complaints from a patient's perspective. Journal of Forensic and ) Legal Medicine: 2013, 20(4), 290-295

\subsection{Satisfied with the procedure, but not with the results?}

In spite of the positive evaluation of the procedures of the Board and the Committee, only half of the patients expressed overall satisfaction. Bearing in mind that our research population consisted only of patients with complaints that were judged founded or at least partially founded, it is puzzling that only half of the patients reported that they are satisfied. Apparently, a good complaints handling procedure is not a guarantee for overall satisfaction. This should not come as a surprise, since the motives to complain are not limited to the correct handling of complaints, but complainants also want something to happen. They want things to change, their feeling of justice to be restored or the accused to be punished. But, most complainants at the Committees as well as the Boards do not believe that professionals or care organisations will make such changes. This explains the finding that only half of the complainants express overall satisfaction in spite of their positive evaluation of either procedure.

Committees, more often than Boards made suggestions for change. This relates to the potential strength of the Committee: its close proximity to the care provider, and the legal obligation of the providers to communicate with the complainant on the changes they make in case of a founded complaint. However, these suggestions, their position and the legal requirements did not lead to a substantially higher number of complainants feeling that the accused will apply these suggestions and make changes. This may explain the finding that the Committee does not outperform the Board in terms over overall satisfaction. On the contrary, when controlling for relevant and known differences in complainants' characteristics, complainants are more satisfied with the Board than with the Committee. Most complainants are not convinced that filing their complaint led to changes, although this was the often the main reason why complainants filed their complaint. A large share of the complainants, especially among those who filed their complaint to a Board, their motive was to see the accused punished. Boards do have the legal power to punish care providers; Committees do not. In the context where complainants find that their complaint did not led to change, the motive to punish the accused may gain importance. This may explain why complainants are more satisfied with the Board. The Committee was expected to do better than the Board, since it was designed to address the most mentioned motive of complainants: change as a result of filing a complaint. But, in practice most complainants do not believe things will change. Hsieh $^{24}$ noticed that in Britain and in Australia attempts are made to create an effective bridge between complaints handling and quality management. Such a bridge was also intended when designing the procedure for the Committees in The Netherlands. Earlier, Bark et al. ${ }^{14}$ found that complaints should be resolved without recourse of formal procedures. An informal procedure, such as conciliation or mediation, allows for a dialogue and encourages suggestions for improvement. ${ }^{25}$ The patient can directly ask for an explanation, apology or an assurance that lessons have been learned. It seems that Committees in The Netherlands operate in a rather formal way. The advantage for complainants is the clarity of a correct procedure. This leads to complainants being positive about this procedure. But this formal procedure does not deliver the desired outcome: change. It would be worthwhile to see whether a procedure with a more informal structure, but still providing a basic degree of procedural safety, will lead to more change and thus to more overall satisfaction. 
Friele, R.D., Kruikemeier, S., Rademakers, J.J.D.J.M., Coppen, R. Comparing the outcome of tyro different procedures to handle complaints from a patient's perspective. Journal of Forensic and ) Legal Medicine: 2013, 20(4), 290-295

\section{ETHICAL APPROVAL}

Not required.

\section{FUNDING}

Funding was received from The Federation of Patients and Consumer Organisations in the Netherlands (NPCF).

\section{CONFLICT OF INTEREST}

Authors report no conflict of interest.

\section{ACKNOWLEDGEMENTS}

The authors want to thank Jayne Judd for her corrections to the English.

\section{REFERENCES}

1. Daniel AE, Burn RJ, Horarik S. Patients' complaints about medical practice. The Medical Journal of Australia 1999;170(12):598e602.

2. Nordlund YG, Edgren L. Patient complaint systems in health care a comparative study between the Netherlands and Sweden. European Journal of Health Law 1999;6(2):133e54.

3. Lister G, Rosleff F, Boudioni M, Dekkers F, Jakubowski E, Favelle H. Handling complaints in health and social care: international lessons for England. London: National Audit Office; 2008.

4. Kuosmanen L, Kaltiala-Heino R, Suominen S, Kärkkäinen J, Hätönen $H$, Ranta S, et al. Patient complaints in Finland 2000e2004: a retrospective register study. Journal of Medical Ethics 2008;34:788e92.

5. Dew K, Roorda M. Institutional innovation and the handling of health complaints in New Zealand: an assessment. Health Policy 2001;57:27e44.

6. Schäfer W, Kroneman M, Boerma W, van den Berg M, Westert G, Devillé W, et al. The Netherlands: health system review. Health systems in transition. 12 ed 2010. 1e229.

7. Hout FAG, Friele RD, Legemaate J. De burger als klager in het tuchtrecht voor de gezondheidszorg [The citizen as a complainant in the disciplinary system for health care]. Ned Tijdschr Geneeskd 2009;153:A548.

8. Kline TJB, Willness C, Ghali WA. Predicting patient complaints in hospital settings. Quality Safety in Health Care 2008;17:346e50.

9. Saravanan B, Ranganathan E, Jenkinson LR. Lessons learned from complaints by surgical patients. Clinical Governance: An International Journal 2007;12(3): $155 \mathrm{e} 8$.

10. Javetz R, Stern Z. Patients' complaints as a management tool for continuous quality improvement. Journal of Management in Medicine 1996;10(3):39e49.

11. Friele RD, Sluijs EM. Patient expectations of fair complaint handling in hospitals: empirical data. BMC Health Services Research 2006;6:106.

12. Doig G. Responding to formal complaints about the emergency department: lessons from the service marketing literature. Emergency Medicine Australasia 2004;16(4):353e60.

13. Dyer C. Patients, but not doctors, like mediation for settling claims. British Medical Journal 2000;320:336.

14. Bark P, Vincent $C$, Jones A, Savory J. Clinical complaints: a means of improving quality of care. Quality in Health Care 1994;3(3):123e32.

15. Bismark M, Dauer E, Paterson R, Studdert D. Accountability sought by patients following adverse events from medical care: the New Zealand experience. Canadian Medical Association Journal 2006;175(8):889e94.

16. Vincent $C$, Young M, Phillips A. Why do people sue their doctors? A study of patients and relatives taking legal action. The Lancet 1994;343:1609e13.

17. Friele RD, Sluijs EM, Legemaate J. Complants handling in hospitals: an empirical study of discrepancies between patients' expectations and their experiences. BMC Health Services Research 2008;8:199. 
Friele, R.D., Kruikemeier, S., Rademakers, J.J.D.J.M., Coppen, R. Comparing the outcome of tyro different procedures to handle complaints from a patient's perspective. Journal of Forensic and )

Legal Medicine: 2013, 20(4), 290-295

18. McColl-Kennedy JR, Sparks BA. Application of fairness theory to service failures and service recovery. Journal of Service Research (JSR) 2003;5(3):251e66.

19. Bismark MM, Spittal MJ, Gogos AJ, Gruen RL, Studdert DM. Remedies sought and obtained in healthcare complaints. BMJ Quality \& Safety 2011;20(9): 806e10.

20. Hout FAG. The Dutch disciplinary system for health care: an empirical study.

Amsterdam: Vrije Universiteit; 2006.

21. Cuperus-Bosma JM, Hout FAG, Hubben JH, Van der Wal G. Views of physicians, disciplinary board members and practicing lawyers on the new statutory disciplinary system for health care in The Netherlands. Health Policy 2006;77(2):202e11.

22. Friele RD, Ruiter Cd, Wijmen Fv, Legemaate J. Evaluatie wet klachtrecht cliënten zorgsector [Evaluation of the clients' right of complaint act]. Utrecht: ZonMw 1999:91.

23. Sluijs EM, Friele RD, Hanssen JE. De WKCZ-klachtbehandeling in ziekenhuizen: verwachtingen en ervaringen van cliënten [Complaints handling in hospitals; patients' expectations and experiences]. Den Haag: ZonMw 2004:115e38.

24. Hsieh YS. Taking patients' voices into account within quality systems: a comparative study. International Journal of Health Care Quality Assurance 2009;22(3):289e99.

25. Pietroni PC, De Uray-Ura D. Informal complaints procedure in general practice: first year's experience. British Medical Journal 1994;308:1546e9. 
Friele, R.D., Kruikemeier, S., Rademakers, J.J.D.J.M., Coppen, R. Comparing the outcome of tyro different procedures to handle complaints from a patient's perspective. Journal of Forensic and Legal Medicine: 2013, 20(4), 290-295

TABLE AND BOX

Box 1. Major differences between the Statutory Disciplinary System (the Disciplinary Board) and the Clients Right of Complaint Act (the Complaints Committees).

\begin{tabular}{|c|c|c|}
\hline & Disciplinary Board & $\begin{array}{l}\text { Complaints } \\
\text { Committee }\end{array}$ \\
\hline Applies for & $\begin{array}{l}\text { Physicians, dentists, } \\
\text { pharmacists, midwives, } \\
\text { nurses, physiotherapists } \\
\text { and health care psychologist }\end{array}$ & $\begin{array}{l}\text { All health care } \\
\text { institutions and } \\
\text { professionals }\end{array}$ \\
\hline Objective & $\begin{array}{l}\text { To foster and monitor the } \\
\text { quality of professional } \\
\text { practice and to protect } \\
\text { the general public, within } \\
\text { the context of legal regulations, } \\
\text { jurisprudence and self-regulation } \\
\text { that regulate the quality of care }\end{array}$ & $\begin{array}{l}\text { To warrant easily } \\
\text { accessible non-legal } \\
\text { complaint facilities } \\
\text { for patients and to } \\
\text { restore patient's } \\
\text { satisfaction with } \\
\text { and trust in health } \\
\text { care }\end{array}$ \\
\hline Procedure & $\begin{array}{l}\text { The Board investigates the } \\
\text { complaint, there will be a } \\
\text { session of the court and the } \\
\text { board makes a judgement } \\
\text { concerning the legitimacy } \\
\text { of the complaint. }\end{array}$ & $\begin{array}{l}\text { The commission } \\
\text { reviews the complaint, } \\
\text { investigates and } \\
\text { makes a decision } \\
\text { concerning the } \\
\text { legitimacy of the } \\
\text { complaint. The } \\
\text { decision is based } \\
\text { on the statements } \\
\text { of the patient and } \\
\text { accused. }\end{array}$ \\
\hline Outcome & $\begin{array}{l}\text { A variety of sanctions (a warning, } \\
\text { a reprimand, suspension, } \\
\text { temporally prohibition to work } \\
\text { and revocation of licenses); } \\
\text { An appeal can be submitted } \\
\text { to the Central Disciplinary } \\
\text { Board }\end{array}$ & $\begin{array}{l}\text { Give advice or } \\
\text { recommend a solution } \\
\text { to the healthcare } \\
\text { provider or } \\
\text { professionals; } \\
\text { The health care } \\
\text { institution is legally } \\
\text { obliged to inform the } \\
\text { patient whether or } \\
\text { not (corrective) } \\
\text { measures will be } \\
\text { taken, and which } \\
\text { measures will be } \\
\text { taken; Appeals are } \\
\text { not possible }\end{array}$ \\
\hline $\begin{array}{l}\text { Total number } \\
\text { of complaints } \\
\text { in } 2008\end{array}$ & $\begin{array}{l}1368 \text { complaints to all Boards } \\
\text { in The Netherlands }\end{array}$ & $\begin{array}{l}3343 \text { complaints to } \\
\text { all hospital based } \\
\text { Committees in The } \\
\text { Netherlands }\end{array}$ \\
\hline
\end{tabular}


Friele, R.D., Kruikemeier, S., Rademakers, J.J.D.J.M., Coppen, R. Comparing the outcome of tyro different procedures to handle complaints from a patient's perspective. Journal of Forensic and Legal Medicine: 2013, 20(4), 290-295

Table 1

Patient and complaint characteristics.

\begin{tabular}{|c|c|c|c|}
\hline $\begin{array}{l}\text { Demographic } \\
\text { characteristics }\end{array}$ & $\begin{array}{l}\text { Disciplinary } \\
\text { Board } \\
(N=80)\end{array}$ & $\begin{array}{l}\text { Complaints } \\
\text { Committee } \\
(N=335)\end{array}$ & $p$ value \\
\hline Females & $46 \%$ & $60 \%$ & 0.016 \\
\hline $\begin{array}{l}\text { With higher professional or } \\
\text { university education }\end{array}$ & $72 \%$ & $49 \%$ & 0.000 \\
\hline Age, mean & 52 yrs & 57 yrs & 0.002 \\
\hline Age, range & $23-85$ yrs & $18-88$ yrs & \\
\hline \multicolumn{4}{|l|}{$\begin{array}{l}\text { Reported impact of event giving } \\
\text { rise to complaint }\end{array}$} \\
\hline $\begin{array}{l}\text { Gave rise to physical discomfort, } \\
\text { pain, handicap or death }\end{array}$ & $63 \%$ & $65 \%$ & NS \\
\hline Gave rise to mental suffering & $81 \%$ & $80 \%$ & NS \\
\hline Had financial consequences & $76 \%$ & $57 \%$ & 0.002 \\
\hline \multicolumn{4}{|l|}{ Made a claim for financial compensation } \\
\hline Made a claim for financial compensation & $38 \%$ & $20 \%$ & 0.001 \\
\hline \multicolumn{4}{|l|}{ Nature of the complaint } \\
\hline Concerned medical treatment & $59 \%$ & $63 \%$ & NS \\
\hline Concerned interpersonal conduct & $58 \%$ & $57 \%$ & NS \\
\hline Concerned lack of information & $34 \%$ & $39 \%$ & NS \\
\hline Concerned organisation of care & $11 \%$ & $37 \%$ & 0.000 \\
\hline Concerned nursing care & $10 \%$ & $32 \%$ & 0.000 \\
\hline
\end{tabular}


Friele, R.D., Kruikemeier, S., Rademakers, J.J.D.J.M., Coppen, R. Comparing the outcome of tyro different procedures to handle complaints from a patient's perspective. Journal of Forensic and Legal Medicine: 2013, 20(4), 290-295

Table 2

Motives to lodge a complaint. ${ }^{\mathrm{a}}$

\begin{tabular}{lll}
$\begin{array}{l}\text { Disciplinary } \\
\text { Board }\end{array}$ & $\begin{array}{l}\text { Complaints } \\
\text { Committee } \\
(N=80)\end{array}$ & $\begin{array}{l}p \text { value } \\
(N=335)\end{array}$ \\
\hline
\end{tabular}

Correction:

To prevent the incident happening to others

$90 \%$

$95 \%$

0.006

To prevent the incident being kept private

The incident be known at a higher level

To prevent the incident happening to me again

$70 \%$

$67 \%$

NS

Communication:

To tell what happened

Restoration:

Restoration feelings of justice

Be able to get back to my normal life

Restore damage that has been done

Solution to my problem

Accountability:

To punish the accused
$84 \%$

$50 \%$

$58 \%$

$57 \%$

$56 \%$

$34 \%$

0.000

The percentage presented in this table is based on the combination of score 3 and 4 of each variable.

${ }^{a}$ Items were measured and tested using a four point scale. 
Friele, R.D., Kruikemeier, S., Rademakers, J.J.D.J.M., Coppen, R. Comparing the outcome of tyro different procedures to handle complaints from a patient's perspective. Journal of Forensic and Legal Medicine: 2013, 20(4), 290-295

Table 3

Patient's experiences with the way complaints were treated. ${ }^{\mathrm{a}}$

\begin{tabular}{|c|c|c|c|}
\hline \multicolumn{4}{|l|}{ The committee or the board } \\
\hline & $\begin{array}{l}\text { Disciplinary } \\
\text { Board } \\
(N=80)\end{array}$ & $\begin{array}{l}\text { Complaints } \\
\text { Committee } \\
(N=335)\end{array}$ & $p$ value \\
\hline \multicolumn{4}{|l|}{ Procedural } \\
\hline Remained impartial & $77 \%$ & $76 \%$ & NS \\
\hline $\begin{array}{l}\text { Provided clear information } \\
\text { on the procedure }\end{array}$ & $81 \%$ & $81 \%$ & NS \\
\hline Responded quickly & $58 \%$ & $56 \%$ & NS \\
\hline Explained the verdict & $74 \%$ & $76 \%$ & NS \\
\hline \multicolumn{4}{|l|}{ Empathy } \\
\hline Treated me with respect & $84 \%$ & $89 \%$ & NS \\
\hline $\begin{array}{l}\text { Allowed me to tell what } \\
\text { had happened }\end{array}$ & $91 \%$ & $88 \%$ & NS \\
\hline $\begin{array}{l}\text { Demonstrated empathy } \\
\text { for my experiences }\end{array}$ & $71 \%$ & $77 \%$ & NS \\
\hline \multicolumn{4}{|l|}{ Results } \\
\hline $\begin{array}{l}\text { Made suggestions to the } \\
\text { care provider for change }\end{array}$ & $39 \%$ & $67 \%$ & 0.000 \\
\hline $\begin{array}{l}\text { A perspective to a solution } \\
\text { to the problem emerged }\end{array}$ & $18 \%$ & $30 \%$ & 0.046 \\
\hline \multicolumn{4}{|l|}{ Expected impact } \\
\hline $\begin{array}{l}\text { The patient believes changes } \\
\text { will be made by the hospital/ } \\
\text { organisation }\end{array}$ & $11 \%$ & $29 \%$ & 0.003 \\
\hline $\begin{array}{l}\text { The patient believes changes } \\
\text { will be made by the care } \\
\text { professional (e.g. doctor) }\end{array}$ & $17 \%$ & $19 \%$ & NS \\
\hline
\end{tabular}

The percentage presented in this table is based on the combination of score 3 and 4 of each variable.

${ }^{a}$ Items were measured and tested using a four point scale. 